Open Access

\title{
Investigating the structural relationships of cognitive and affective domains for L2 listening
}

Sujin Bang and Phil Hiver ${ }^{*}$ (D)

\author{
* Correspondence: \\ philiphiver@igse.ac.kr \\ Department of ELT, International \\ Graduate School of English, 17 \\ Yangjae-daero, 81-gil, \\ Gangdong-gu, Seoul 05408, \\ Republic of Korea
}

\begin{abstract}
This study examines the links between L2 linguistic knowledge, L2 listening strategy use, self-determined motivation, and L2 listening anxiety relative to L2 listening proficiency. Prior theoretical and empirical work suggests that these variables are interrelated in complex ways, and this hypothesis is tested here using structural equation modeling with a sample of 300 high school foreign language learners at the lower end of the proficiency spectrum. Our results indicate that intrinsic motivation yielded the strongest impact on L2 listening proficiency, and separately predicted greater self-regulated learning behavior, which in turn predicted lower levels of listening anxiety. L2 listening strategy use was additionally associated with higher levels of L2 linguistic knowledge, but did not directly predict higher L2 listening success. It was only through the mediation of L2 linguistic knowledge that L2 listening strategy use was linked to low L2 listening anxiety and higher overall L2 listening proficiency. These results are discussed, and we suggest that while L2 listening strategy use may be a key factor in reducing L2 listening anxiety, encouraging listening strategy use below a certain level of $L 2$ linguistic knowledge may be of limited effect.
\end{abstract}

Keywords: Self-determined motivation, L2 listening anxiety, L2 listening strategy, L2 linguistic knowledge, L2 listening proficiency

\section{Introduction}

Language learning is a demanding, complex process and involves a variety of factors which operate simultaneously. Within this domain, L2 listening has gained increasing attention from researchers for several reasons. First, because it provides the input necessary to facilitate learning, listening plays an important role in language learning (Vandergrift 2007). It is fundamental to all other skills and influences overall development. Additionally, it is used most frequently in L2 instruction when compared with the other language skills, suggesting that listening skills contribute more to L2 academic success than even reading skills do (Rost 2013). Despite its significance for language development, however, listening may be the most difficult skill to learn due to its nature as the least explicit of all the language skills. Learners achieve greatly varying levels of success in L2 listening; some are skilled listeners while others often remain poor listeners. It is our position that this gap can be accounted for by a web of 
mutually related individual factors encompassing cognitive and affective aspects that influence L2 listening.

Vandergrift and Goh (2012) have pointed out that "many factors are assumed to influence L2 listening, but there is still very little research to provide empirical evidence for a causal relationship" (p. 57). Recent studies focusing on the relationship between multiple factors and L2 listening proficiency have provided a more systematic and comprehensive understanding of L2 listening proficiency (Brunfaut and Révész 2015; Yeldham 2016). Similar to Vandergrift and Goh (2012), we see the ultimate purpose of investigating factors which hinder or facilitate successful L2 listening as being to inform the principled teaching of L2 listening. Therefore, the primary aim of this study is to integrate major cognitive and affective components that influence learners' L2 listening success in a single structural framework, and to identify the complex causal relationships among these factors regarding L2 listening proficiency.

\section{What does L2 listening entail?}

L2 listening can be conceptualized as a multilayered, purposeful process of constructing meaning from aural input (Vandergrift and Goh 2012). It involves not only receiving and deciphering linguistic input but also interpreting and relating the input to what is already known (Vandergrift 2007). L2 listening comprehension also necessitates the overt use of cognitive skills to construct meaning through the process of discriminating, identifying, and connecting linguistic input (Andringa et al. 2012). As part of the multidimensional processing listening requires, such things as phonetics, phonology, lexis, syntax, semantics, and discourse structure are thought to be used in an incremental fashion in the bottom-up decoding process (Buck 2001). Non-linguistic knowledge (e.g., schemata) relates to processes which build a more top-down mental representation of meaning. Listeners are seen as using all of these interactively and purposefully while listening. Another framework sees the process of listening as involving three interrelated and recursive phases: perception, parsing, and utilization (Goh 2000). Due to the inherent complexity of the L2 listening process, success may depend greatly on a concert of individual learner characteristics, and identifying the factors that might lead learners to different levels of success in listening comprehension is meaningful. Vandergrift and Goh (2012), for instance, have previously alluded to person (i.e., cognitive and affective) factors and listening context factors. We now turn to a review of the learner facets thought to affect L2 listening success in order to identify their effects and interrelationships.

\section{Linguistic factors}

Most research appears to address the relationship between L2 linguistic knowledge and L2 reading comprehension (Grabe and Stoller 2013). However, considering that L2 listeners have to rapidly parse words out from a wave of incoming sounds, it is reasonable to presume that L2 linguistic knowledge is a crucial factor in achieving L2 listening success (Nation 2006). L2 vocabulary and grammatical knowledge, the basic elements required to process and understand L2 listening content, can indeed be said to contribute substantially to L2 listening proficiency (Vandergrift 2006). Findings for the relationship between L2 vocabulary knowledge and L2 listening ability reflect those in studies on reading: vocabulary knowledge is a significant factor explaining L2 listening 
ability (van Zeeland and Schmitt 2013a, b). For instance, Mecartty (2000) found that lexical knowledge linked to both L2 reading and L2 listening comprehension in learners of Spanish, and Vandergrift's (2006) study of learners of French in Canada confirmed the importance of lexical knowledge for the listening skill. Evidence is also growing that learners who experience a deficit in L2 vocabulary knowledge will experience significant problems in listening (Taylor and Geranpayeh 2011). In an investigation of Korean language learners, Kim (2008) corroborated this, demonstrating that $52 \%$ of L2 listening ability was accounted for by L2 vocabulary knowledge. Stæhr's (2009) study of advanced Danish learners of English again confirmed that L2 vocabulary knowledge goes hand in hand with L2 listening comprehension, showing that breadth and depth of vocabulary knowledge together explained $51 \%$ of the variance in L2 listening comprehension.

Although vocabulary knowledge and syntactic knowledge are both involved in the perception stage of the listening comprehension process, the difference between the two knowledge types lies in the fact that lexical knowledge is meaning-laden and syntactic knowledge is function-based with regards to how words may be combined in sentences, phrases, or utterances (Rost 2013). Unlike the more straightforward role vocabulary knowledge has been found to play in relation to both L2 reading and listening, the extent to which grammar knowledge contributes to L2 listening comprehension remains underdetermined-largely due to a meager research base (Graham et al. 2010). According to Mecartty (2000), L2 syntactic knowledge explains little variance in either L2 listening and L2 reading comprehension. On the other hand, Shiotsu and Weir (2007) discovered a greater significance in the role for syntactic knowledge than for vocabulary knowledge in predicting L2 reading comprehension. These results suggest that although vocabulary knowledge may be a significant factor for predicting L2 listening proficiency, further empirical clarification is needed on the role of syntactic knowledge in L2 listening.

\section{Listening strategy factors}

There is a consensus that while constructing meaning, a listener's ability to attend to and monitor what they are listening to-their strategic ability-will contribute to their listening comprehension (Rost 2013). Evidence from several decades of research on strategies for language learning indicates that successful learners are aware of the learning process and consciously control how they learn (e.g., Cohen 2014; Griffiths 2013; Griffiths and Oxford 2014), suggesting that successful learners are strategic learners. O'Malley and Chamot (1990) have categorized learning strategies into functional categories for comprehension (i.e., cognitive, meta-cognitive, and socio-affective), while Oxford (1990) provided a taxonomy oriented primarily towards long-term language learning. Following Vandergrift's (1997) taxonomy of L2 listening-specific strategies, a growing body of research has investigated the relationship between strategy use and proficiency in L2 listening (Vandergrift 2008). L2 listening strategies can be defined as techniques which learners use consciously to increase their effectiveness during the listening process (see also Hsiao and Oxford 2002). By emphasizing the type of listening strategies used and how the application of listening strategies differs from learner to learner, these studies show that the active use of various cognitive and meta-cognitive 
listening strategies may help determine which learners are more or less efficient and independent L2 listeners (Vandergrift and Baker 2015; Yeldham and Gruba 2016).

Skilled L2 listening involves "a skillful orchestration of meta-cognitive and cognitive strategies” (Vandergrift 2008, p. 90). Proficient L2 listeners do indeed show greater use of meta-cognitive strategies such as planning, monitoring, evaluating, and problemsolving than less proficient listeners (Vandergrift 2003, 2005). Since meta-cognitive strategies are closely related to directing the listening process, it may be harder for less proficient listeners to use meta-cognitive strategies due to cognitive constraints of processing at the perception level (Goh 2008; Yeldham 2016). Others have also concluded that more proficient listeners appear to be more flexible in changing strategies as they progress through the listening phases (Vandergrift and Tafaghodtari 2010). Less proficient listeners, who often lack flexibility in using listening strategies, either focus too much on the text of the listening or on their background knowledge during listening. These findings suggest that proficient listeners not only possess a wider repertoire of L2 listening strategies to draw from, they also employ these varied meta-cognitive and cognitive strategies more effectively while listening, which suggests that L2 listening strategy use is a major determinant of L2 listening proficiency (Graham and Macaro 2008).

\section{Affective factors}

Along with the cognitive factors of linguistic knowledge and L2 listening strategy use, affective factors play a central role in L2 learners' listening proficiency (Vandergrift and Goh 2012; Vandergrift, 2007). These domains should not be seen as being in competition as relationships between affective and cognitive domains of L2 learning reveal mutually beneficial links that help to build a firmer foundation for success (Dewaele and MacIntyre 2014). Previous studies have established two affective factors which are a major influence on L2 listening proficiency, motivation and anxiety. It is to these two constructs that we now turn.

The affective variable that is most widely reported as having a significant influence on both L2 learning (Horwitz 2001, 2010) and more specifically on listening (Pae 2009, 2013) is anxiety. Anxiety can be broadly defined as a psychological state characterized by feelings of fear, tension or worry, and uneasiness (MacIntyre and Gregersen 2012). The unique characteristics of L2 listening, including one's inability to control the topic, speed, or volume of the speech, have the potential to create the experience of apprehension and helplessness in L2 learners relatively easily (Brunfaut and Révész 2015). Grappling with these negative emotions can greatly impact learners' L2 listening success. Beginning with $\operatorname{Kim}(2002,2005)$, who attempted to establish the existence of L2 listening anxiety empirically, scholars have increasingly concluded that L2 listening anxiety is negatively linked with L2 listening proficiency (Bekleyen 2009; Elkhafaifi 2005; Kim and Park 2006; Mills et al. 2006). However, due to inconsistencies in early studies, most research related to L2 listening anxiety has focused on verifying the underlying structure of L2 listening anxiety. In her initial work, Kim (2002) divided foreign language listening anxiety into two subfactors: lack of confidence and tension and worry. However, these factors and their loadings diverge from what other researchers have found (Lee and Lee 2007; Pae 2009, 2013). 
In striving for a better understanding of motivation for L2 learning, one widely used framework is Deci and Ryan's (1985) self-determination theory (SDT). The underlying premise of SDT is that learners who possess intrinsic motivation perform an activity simply for pleasure and innate satisfaction, whereas those who are extrinsically motivated behave in a particular way in order to receive some rewards or to avoid punishment (Dörnyei 2001; Noels 2009). Rather than a dichotomy, there exist varying degrees of self-determination along a continuum depending on the extent to which regulation is internalized. Extrinsic motivation ranges from external regulation-with the lowest level of self-determination-to introjected regulation, identified regulation, and integrated regulation (Deci and Ryan 2000). Scholarly work more than a decade ago established the validity of the SDT motivational framework for L2 learning (Noels et al. 1999; 2001; Noels et al. 2000). Since then, the utility and significance of self-determined motivation has not diminished (see Boo et al. 2015; Dörnyei and Ushioda 2013). However, despite the importance of SDT for L2 learning, relatively few studies have connected self-determined motivation to L2 listening research, indicating that further research may be needed (Vandergrift 2005, 2007).

\section{Relationships among the factors influencing L2 listening}

As will be clear from our review of relevant literature, each of these cognitive and affective factors contributes empirically to explaining L2 listening ability. However, most of the studies above focus on a link between a single factor and L2 listening proficiency. These individual relationships provide only a partial explanation of learners' success in the complex L2 listening process. Furthermore, the contribution of each factor to L2 listening proficiency may differ due to mutually mediating effects. Our objective here is to review possible links between multiple factors in order to integrate these major factors into a comprehensive framework.

Separately, L2 linguistic knowledge and L2 listening strategy use certainly play a consequential role for L2 listening comprehension (Vandergrift and Goh 2012), but virtually no attention has been paid to the relationship between the two of these. Although the relationship between L2 linguistic knowledge and L2 listening strategy use is under-determined, we might surmise from existing results that L2 linguistic knowledge mediates the impact of L2 listening strategy use on L2 listening. Apart from Pae's (2009) study of major factors affecting L2 listening ability, few studies have examined the relationship between L2 listening anxiety and L2 linguistic knowledge. Pae's (2009, 2013) research has demonstrated that L2 listening anxiety mediates the influence that L2 linguistic knowledge has on L2 listening proficiency. These results suggest that as learners gain greater L2 linguistic knowledge, their L2 listening anxiety decreases resulting in better L2 listening proficiency. Additionally, the link between L2 listening anxiety and L2 linguistic knowledge has also been shown in work investigating the effect of L2 vocabulary instruction as pre-listening support (Chang 2007; Rost 2007). These studies illustrate that learners who are prepared linguistically for L2 listening report lower anxiety levels.

A great deal of attention has been drawn toward the facilitative potential of L2 learning strategy use for L2 development (Vandergrift 2008). Furthermore, because strategy use encompasses cognitive and behavioral facets of language learning, there is an 
underlying realization that "strategies are, by definition, examples of motivated learning behavior" (Dörnyei and Ryan 2015, p. 152). In listening as well, strategy use is strongly correlated with L2 learning motivation. For example, Vandergrift (2005) investigated the relationship between subtypes of self-determined motivation and L2 listening strategy use in his study of 57 adolescent learners of French, and found that greater use of meta-cognitive L2 listening strategies is linked to the more self-determined forms of motivation. Pae's (2009) study of the structural relationships among factors affecting L2 listening proficiency established that among the self-determined motivation types, only intrinsic motivation had a direct relationship with L2 listening strategy use and significantly affected L2 listening proficiency. The results also showed that intrinsic motivation had an indirect influence on L2 listening proficiency mediated through L2 listening strategy use. Effectively, L2 listening strategies are only employed based on the existence of motivation. Among the subtypes of self-determined motivation, more intrinsic forms of motivation are significantly correlated with L2 strategy use and with L2 listening proficiency, suggesting that L2 listening strategy use plays an important mediating role between self-determined motivation and L2 listening proficiency.

Studies, particularly in foreign language instructional settings, have confirmed the seemingly commonsense observation that L2 listening anxiety is negatively linked with L2 listening strategy use (Jung 2004; Kim and Park 2006; Lee and Lee 2007). For instance, Jung (2004) examined the relationship between L2 listening strategies and L2 listening anxiety of Korean, Chinese, and Japanese university students of English. As expected, the results for all three groups of students indicated that listening strategy use had a negative relationship with listening anxiety. However, focused findings diverged depending on the nationality of learners: listening strategy use was the only predictor for L2 listening proficiency in Korean participants, while L2 listening anxiety was a better predictor than L2 listening strategy use for the Chinese and Japanese respondents. This latter finding was echoed in Kim and Park's (2006) study which found that L2 listening success was influenced more strongly by L2 listening anxiety than by L2 listening strategy use. Pae's (2009) study went one better, and showed that L2 listening strategy use, mediated through L2 listening anxiety, influenced L2 listening proficiency.

\section{Research model and hypotheses}

As we have highlighted above, previous studies exploring the factors thought to influence L2 listening proficiency have focused on the major factors in an isolated manner. However, there is a clear need to investigate the causal relationships among the major factors affecting L2 listening proficiency in a robust integrated framework.

To investigate the relationships among the factors affecting L2 listening proficiency, a structural model has been postulated based on the combined empirical evidence and theoretical considerations (Fig. 1). For the purposes of this structural model, selfdetermined motivation was chosen as an exogenous variable, while L2 listening strategy use, L2 listening anxiety, L2 linguistic knowledge, and L2 listening proficiency were chosen as endogenous variables.

Accompanying this postulated model are ten hypotheses which, when combined, may explain much of what determines L2 listening proficiency. These hypotheses are: 


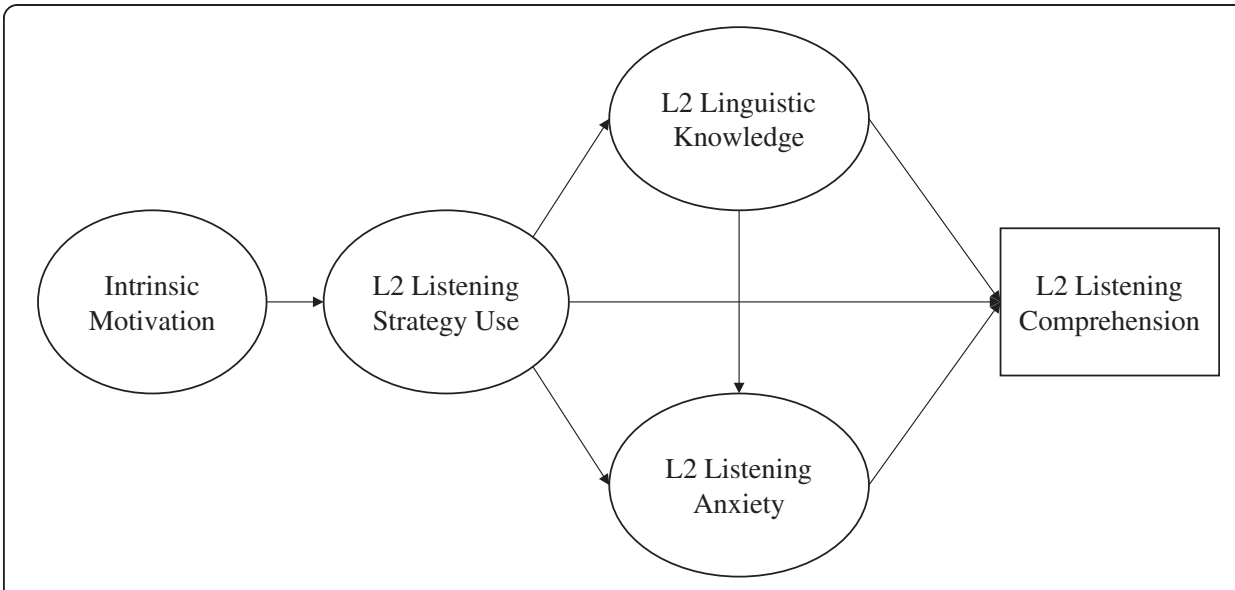

Fig. 1 Theoretical structural model specification

H1: Self-determined motivation will directly affect L2 listening strategy use.

H2: Self-determined motivation will indirectly affect L2 linguistic knowledge, mediated through L2 listening strategy use.

H3: Self-determined motivation will indirectly affect L2 listening anxiety, mediated through L2 linguistic strategy use as well as through L2 linguistic knowledge.

H4: Self-determined motivation will indirectly affect L2 listening proficiency, mediated through L2 listening strategy use, L2 linguistic knowledge, and L2 listening anxiety.

H5: L2 listening strategy use will directly affect L2 linguistic knowledge.

H6: L2 listening strategy use will directly affect L2 listening anxiety.

H7: L2 listening strategy use will directly affect L2 listening proficiency and will also indirectly affect L2 listening proficiency, mediated through L2 linguistic knowledge.

H8: L2 linguistic knowledge will directly affect L2 listening anxiety.

H9: L2 linguistic knowledge will directly affect L2 listening proficiency and will also indirectly affect L2 listening proficiency, mediated through L2 listening anxiety.

H10: L2 listening anxiety will directly affect L2 listening proficiency.

\section{Method}

\section{Participants}

Participants $($ male $=137$, female $=163)$ were L2 learners of English from six high schools: three located in educationally competitive school districts Seoul, Korea, and three located in the most densely populated regions immediately surrounding the capital. These respondents all volunteered to take part in the study and were all treated in accordance with APA ethical guidelines.

We intentionally sampled students toward the lower end of the proficiency spectrum (from beginner to lower-intermediate ability levels), and several additional sampling criteria were applied to participant selection to ensure that our respondents were typical of high school students in this foreign language context: they were all first (107) and second (193) year students who had begun formal L2 learning between the ages of 7 and 10. Respondents also reported routinely spending between 6 and 8 h in independent L2 study outside the compulsory classroom setting. They had all spent fewer than six months in L2 study abroad experiences. 
Despite Korea's distinctive obsession with education, as a learning context it could be considered somewhat typical of most contexts where second and foreign languages are taught-given that classroom instruction involves long hours of preparation for mandated high-stakes tests. (Butler 2015; Hu and McKay 2012). However, considering our choice of participants, the L2 learning experiences of these respondents may not be broadly generalizable, and thus their results should be seen as more representative of this particular context than other parallel settings.

\section{Instruments}

\section{L2 vocabulary knowledge}

We used the Vocabulary Levels Test (VLT) as a measurement of participants' L2 vocabulary knowledge because of its acknowledged validity and reliability (Schmitt et al. 2001). For this study, only levels 2,000 and 3,000 were used because the Korean Ministry of Education, Science and Technology (MEST, 2011) mandates a level of 2,315 words for upper-secondary school learners. The representative vocabulary score for individual participants was an aggregated score of levels 2000 and 3000.

\section{L2 syntactic knowledge}

In order to measure the syntactic knowledge of these L2 learners, we borrowed the multiple-choice format of the Korean MEST grammar tests and adapted the content to include 20 items that each assessed a discrete point of syntactic knowledge. Discrete points of grammatical knowledge tested in the 20 items included knowledge of (a) agreement; (b) modifiers; (c) coordinating elements, subordination, reduction, and apposition, (d) prepositions; and (e) proper order of the elements in sentences. The grammar score of individual participants was presented as the sum of these 20 items, and the reliability coefficient of this test $(\alpha=.85)$ indicated acceptable reliability in our sample. Combined with L2 vocabulary knowledge, this made up the latent variable L2 linguistic knowledge.

\section{L2 listening proficiency}

To measure the participants' L2 listening proficiency, we administered the standardized TOEFL Junior ${ }^{\circ}$ listening comprehension test. The reliability alpha for this test of L2 listening proficiency was .85 .

In addition to the three tests above, we developed a survey for this study to measure L2 listening strategy use, L2 listening anxiety, and self-determined motivation. We compiled a pool of items from existing scales. Through item analysis we reduced the scales to increase reliability, resulting in a final survey instrument composed of 48 items across the three constructs. Participants responded to all statements on a 5-point response scale (anchors: 1 = strongly disagree; 5 = strongly agree).

L2 Listening Strategy Use - 18 items adapted from Vandergrift (1997) were split evenly between metacognitive strategies $(\alpha=.79)$, and cognitive strategies $(\alpha=.78)$. The first of these relates to how a listener develops a series of conscious steps to perform a listening task, while the second concerns how a listener manipulates information to aid comprehension.

Self-determined Motivation - 18 items were adapted from the Language Learning Orientations Scale (Noels et al. 2000) in the scales of external regulation $(\alpha=.79)$, introjected regulation $(\alpha=.81)$, identified regulation $(\alpha=.86)$, and the subcategories of 
knowledge $(\alpha=.74)$, accomplishment $(\alpha=.77)$, and stimulation $(\alpha=.70)$ that make up the intrinsic motivation scale.

L2 Listening Anxiety - we initially adopted 20 items from the Foreign Language Listening Anxiety Scale (Kim 2005). However, due to inconsistent results with the subfactors of this construct in EFA, items were examined through unidimensional confirmatory factor analysis and all items with a factor loading value of less than .7 were eliminated. The final L2 listening anxiety scale $(\alpha=.70)$ adopted for our measurement model included just two items and did not use an item parceling technique.

\section{Procedure}

Piloting of the survey, the grammar test, and L2 listening test took place with L2 learners in two high schools from an adjacent region to ensure the reliability of the instruments prior to our main study. Questionnaires were translated into the students' L1 by a non-affiliated researcher familiar with the principles of questionnaire construction and both languages in question, and then back-translated by us. Due to the comprehensive materials we sought to administer, we anticipated difficulty in recruiting participants, and so began by approaching contacts in the teaching faculty of high schools region-wide during the first few weeks of the school year. Research assistants then informed students from participating schools about the purpose of the data we would be collecting. The final L2 vocabulary test, L2 listening proficiency test, L2 grammar test, and 48-item questionnaire were completed by the students who agreed to participate during study-hall periods in the final weeks of the spring semester.

\section{Data analysis}

In order to determine the measured variables for self-determined motivation, we first performed a stepwise multiple regression so that only statistically significant measured variables for L2 listening proficiency were included in the measurement model. We then calculated Pearson's correlation coefficients to examine the existence of significant correlations among the pertinent variables regarding L2 listening proficiency. Following this, we conducted a structural equation model (SEM) in AMOS 22 using maximumlikelihood estimation to examine the causal relationships among the cognitive and affective variables thought to influence L2 listening proficiency.

We followed the recommended two-step approach (Kline 2010) of testing the measurement model before building the structural model. In the measurement model, the mutual relationships among the measured variables and hypothesized latent variables were estimated through a confirmatory factor analysis (CFA) to verify the convergent and discriminant validity of the model. Once the CFA indicated it was appropriate to move to the structural model, we examined the regression coefficients that indicate the causal relationships of each latent variable to one another with regards to L2 listening proficiency. To determine whether the suggested model fit the data, we examined complementary model fit indices $\left(\chi^{2}\right.$, RMSEA, CFI, TLI), and modified the proposed model by deleting non-significant parameters. After determining the final model we verified the significance levels of the total effects, direct effects, and indirect effects among the pertinent variables for L2 listening proficiency using a bootstrapping technique. 


\section{Results and discussion}

The purpose of this study was to examine the structural relationships among four cognitive and affective factors and their impact on L2 listening proficiency, and to integrate these in a single framework. First, Pearson's correlation coefficients were obtained to examine the interrelationships among the subtypes of self-determined motivation and L2 listening proficiency. The results indicated that the strength of these correlations gradually increases as learners' motivation becomes more self-determined (Table 1).

We then performed a stepwise multiple regression analysis to determine which subtypes of self-determined motivation were significant predictors for L2 listening proficiency, and should thus be included in the measurement model as latent variables. Residuals were normally distributed around the predicted listening scores and had a linear relationship with them, while the criterion variables' variance inflation factors (VIFs) indicated that there were no multicollinearity problems. Only intrinsic motivation was found to have a significant impact on L2 listening proficiency (Table 2). The negative regression coefficients of external regulation and introjected regulation, while not statistically significant, did mirror the results of previous studies on L2 listening proficiency (Pae 2009).

We, thus, decided to include only intrinsic motivation-measured through its three sub-factors-as a latent variable for the measurement model. We also noted the particularly low $R^{2}$ value-intrinsic motivation accounted for only $4.1 \%$ of the variance of L2 listening proficiency-signaling the possible existence of other mediating variables, hence justifying further probing into the structural relationship among the factors affecting L2 listening proficiency.

\section{The measurement model}

In our measurement model, we first examined correlations between each measured variable (Table 3). With the exception of correlations between the subfactors of intrinsic motivation and the anxiety 2 variable, and accomplishment and anxietyl, all these coefficients were statistically significant. Using maximum likelihood estimation, we then conducted a confirmatory factor analysis (CFA). The measurement variables all met the conditions for standard normal distribution in SEM analysis. Apart from the measured variables in L2 listening anxiety, which were chosen through a unidimensional CFA, all of the measured variables were aggregated through an item-parceling process.

Figure 2 shows the measurement model. To examine convergent validity (i.e., that the measured variables represent their latent constructs), three aspects were investigated.

Table 1 Correlation matrix of the measured variables

\begin{tabular}{lllllll}
\hline Measured variables & $M$ & $S D$ & 1 & 2 & 3 & 4 \\
\hline 1. External Regulation & 3.68 & .74 & - & & & \\
2. Introjected Regulation & 3.03 & .75 & $.585^{* *}$ & - & \\
3. Identified Regulation & 3.84 & .71 & $.290^{* *}$ & $.513^{* *}$ & - & \\
4. Intrinsic Motivation & 2.97 & .86 & $.136^{*}$ & $.445^{* *}$ & $.673^{* *}$ & - \\
L2 Listening Proficiency & - & - & -.033 & -.003 & $.181^{* *}$ & $.207^{* *}$ \\
\hline
\end{tabular}

Note. $N=300$

** $p \leq .01$

${ }^{*} p \leq .05$ 
Table 2 Multiple regression of predictor variables for $L 2$ listening proficiency

\begin{tabular}{lllll}
\hline Criterion variable & $\beta$ & $t$ & $p$ & VIF \\
\hline External Regulation & -.063 & -1.097 & .274 & 1.019 \\
Introjected Regulation & -.118 & -1.880 & .061 & 1.246 \\
Identified Regulation & .075 & .984 & .326 & 1.827 \\
Intrinsic Motivation & .207 & 3.655 & $.000^{* * *}$ & 1.000 \\
\hline
\end{tabular}

Note. $N=300 . \mathrm{DV}=\mathrm{L} 2$ Listening Proficiency, $R^{2}=.041$

${ }^{* * *} p<.001$

First, as a rule of thumb, construct reliability (CR) must be .7 or higher, a condition which was satisfied for the three constructs as shown in Table 4. Second, the average variance extracted (AVE) should be .5 or higher, and this condition too was met. As a final rule of thumb, standardized factor loadings of each indicator variable should be .5 or higher. All factor loadings were statistically significant and higher than this threshold. Since L2 linguistic knowledge does not comprise psychological constructs, the CR and the AVE were not calculated.

To establish discriminant validity (i.e., that the constructs are distinct from each other), the squared correlations coefficients $\left(r^{2}\right)$ between the latent variables should be less than the AVE of each variable. Table 5 shows that this condition was also satisfied.

The model fit indices for the measurement model were also satisfactory, $\chi^{2}(20)=32.47$, $p=$ n.s, $\mathrm{CMIN} / d f=1.623, \mathrm{TLI}=.982, \mathrm{CFI}=.990, \mathrm{RMSEA}=.046$. Taken together, these results suggested that it was safe to proceed to the structural model.

\section{The structural model}

The proposed structural model fit index indicated a moderate model fit that was nevertheless statistically significant, $\chi^{2}(29)=56.536, p=.002, \mathrm{CMIN} / d f=1.95$, TLI $=.973$, CFI $=.982$, RMSEA $=.056$. All of the path loadings in this proposed model were significant at the level of .05 except for a structural path linking L2 listening strategy use to L2 listening proficiency. Based on this, we modified our model by first removing the path from L2 listening strategy use to L2 listening proficiency, and then by connecting measurement errors. The fit index of this final model was acceptable, $\chi^{2}(29)=44.383, p=\mathrm{n} . \mathrm{s}$, $\mathrm{CMIN} / d f=1.53, \mathrm{TLI}=.983, \mathrm{CFI}=.990, \mathrm{RMSEA}=.042$. The chi-square invariance test comparing the proposed model with the modified model indicated no difference between the two nested models $\left(\Delta \chi^{2}(1)=1.89<3.84\right)$; the final model was therefore accepted for this study.

As Table 6 shows, the path loadings of this finalized structural model are all statistically significant. The squared multiple correlations of the final structural model indicate that intrinsic motivation explained $35.2 \%$ of the variance in L2 listening strategy use, while intrinsic motivation and L2 listening strategy use together contributed to explaining $23.5 \%$ of the variance in L2 linguistic knowledge. Additionally, intrinsic motivation, L2 listening strategy use, and L2 linguistic knowledge explained $42.2 \%$ of L2 listening anxiety. Finally, 68 \% of L2 listening proficiency was accounted for by all the variables together.

In order to better understand the final structural model, we examined the direct effects, indirect effects, and total effects among the variables thought to influence L2 listening proficiency. Table 7 shows that, with the sole exception of hypothesis 7 (i.e., that 
Table 3 Correlation matrix of the measurement variables

\begin{tabular}{|c|c|c|c|c|c|c|c|c|c|c|c|c|}
\hline & M & SD & 1 & 2 & 3 & 4 & 5 & 6 & 7 & 8 & 9 & 10 \\
\hline 1. Cognitive Listening Strategies & 3.41 & .596 & - & & & & & & & & & \\
\hline 2. Meta-cognitive Listening Strategies & 3.26 & .541 & $.638^{* *}$ & - & & & & & & & & \\
\hline 3. Stimulation & 2.72 & .994 & $.407^{* *}$ & $.427^{* *}$ & - & & & & & & & \\
\hline 4. Knowledge & 2.80 & .932 & $.397^{* *}$ & $.444^{* *}$ & $.754^{* *}$ & - & & & & & & \\
\hline 5. Accomplishment & 3.18 & .948 & $.309^{* *}$ & $.432^{* *}$ & $.647^{* *}$ & $.716^{* *}$ & - & & & & & \\
\hline 6. Anxiety 1 & 2.52 & 1.05 & $-.319^{* *}$ & $-.226^{* *}$ & $-.112^{* *}$ & $-.058^{* *}$ & .032 & - & & & & \\
\hline 7. Anxiety2 & 2.77 & 1.04 & -.357 & -.321 & -.259 & -.204 & -.207 & .546 & - & & & \\
\hline 8. L2 Vocabulary Knowledge & 43.9 & 14.5 & $.379^{* *}$ & $.377^{* *}$ & $.286^{* *}$ & $.232^{* *}$ & $.204^{* *}$ & $-.402^{* *}$ & $-.439 * *$ & - & & \\
\hline 9. L2 Syntactic Knowledge & 14.0 & 4.68 & $.268^{* *}$ & $.291^{* *}$ & $.198^{* *}$ & $.187^{* *}$ & $.124^{*}$ & $-.370^{* *}$ & $-.373^{* *}$ & $.784^{* *}$ & - & \\
\hline 10. L2 Listening Proficiency & 11.3 & 3.48 & $.370^{* *}$ & $.370^{* *}$ & $.249^{* *}$ & $.191^{* *}$ & $.137^{*}$ & $-.496^{* *}$ & $-.460^{* *}$ & $.741^{* *}$ & $.683^{* *}$ & 一 \\
\hline
\end{tabular}

Note. $N=300$

${ }^{* *} p \leq .01$
${ }^{*} p \leq .05$ 


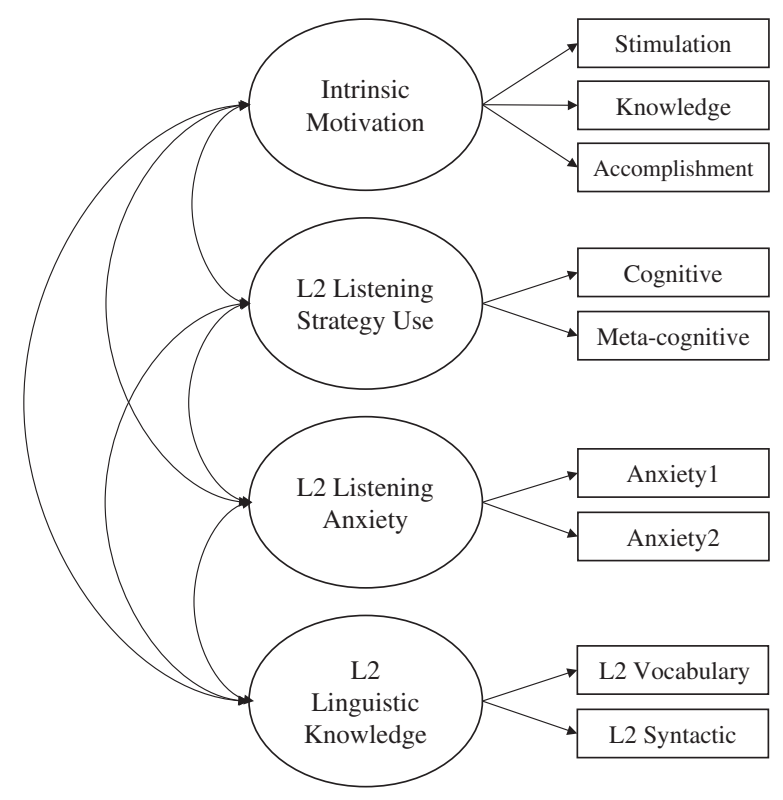

Fig. 2 Final measurement model. Error indicators were omitted for simplicity

L2 listening strategy use will affect L2 listening proficiency directly), all hypotheses postulated at the beginning of this study were supported by this final model. It appears that-through the mediating variable L2 linguistic knowledge-full mediation occurred between L2 listening strategy use and L2 listening proficiency.

As can be seen from Fig. 3, intrinsic motivation exerted a direct effect only on L2 listening strategy use, while it had an indirect effect on all the other variables. Intrinsic motivation only indirectly affected L2 listening proficiency, mediated through L2 listening strategy use, L2 linguistic knowledge, and L2 listening anxiety. For its part, L2 listening strategy use had a direct effect on both L2 linguistic knowledge and L2 listening anxiety, whereas it had an indirect effect on both L2 listening anxiety and L2

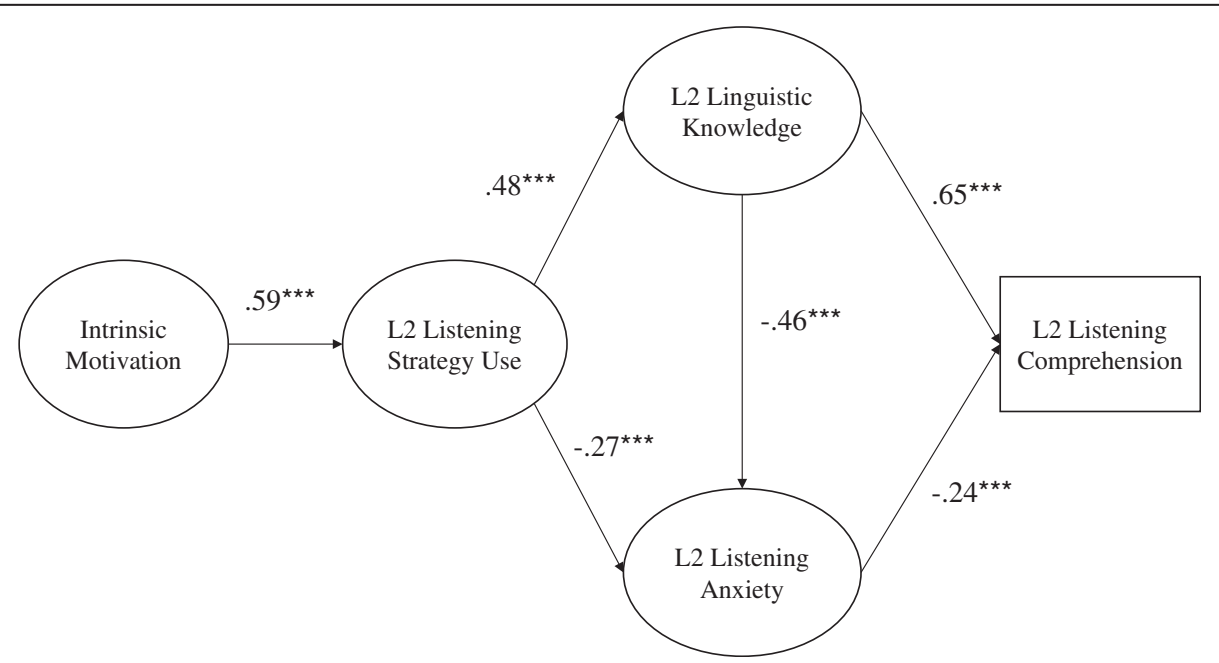

Fig. 3 Final structural model. Covariances and indicators were omitted for simplicity. Standardized coefficients shown. ${ }^{* * *} p<.001$ 
Table 4 Model fit indices of measured variables

\begin{tabular}{|c|c|c|c|c|c|c|}
\hline \multicolumn{2}{|l|}{ Variables } & \multirow[t]{2}{*}{$\beta$} & \multirow[t]{2}{*}{ S.E. } & \multirow[t]{2}{*}{$p$} & \multirow[t]{2}{*}{$C R$} & \multirow[t]{2}{*}{ AVE } \\
\hline Latent & Measured & & & & & \\
\hline \multirow[t]{3}{*}{ Intrinsic Motivation } & Accomplish & .777 & & & .887 & .724 \\
\hline & Knowledge & .902 & .072 & $* * *$ & & \\
\hline & Stimulation & .835 & .075 & $* * *$ & & \\
\hline \multirow[t]{2}{*}{ L2 Listening Anxiety } & Anxiety 1 & .696 & & & .762 & .617 \\
\hline & Anxiety 2 & .790 & .123 & $* * *$ & & \\
\hline \multirow[t]{2}{*}{ L2 Listening Strategy Use } & Meta-cognitive & .813 & & & .916 & .845 \\
\hline & Cognitive & .785 & .095 & $* * *$ & & \\
\hline \multirow[t]{2}{*}{ L2 Ling. Knowledge } & Grammar & .801 & & & - & - \\
\hline & Vocabulary & .978 & .305 & $* * *$ & & \\
\hline
\end{tabular}

${ }^{* * *} p \leq .001$

listening proficiency. Furthermore, the indirect effect it exerted on L2 listening proficiency was mediated through L2 linguistic knowledge and L2 listening anxiety. On the other hand, L2 linguistic knowledge had both a direct and indirect impact on L2 listening proficiency - the latter mediated through L2 listening anxiety. L2 linguistic knowledge also had a direct effect on L2 listening anxiety, while L2 listening anxiety exerted an effect only on L2 listening proficiency.

In order to estimate the individual contributions of mediation paths, the indirect effect sizes of the variables on L2 listening proficiency were calculated by multiplying the standardized direct effect sizes between latent variables. As Table 8 shows, the path "L2 listening strategy $\rightarrow$ L2 linguistic knowledge $\rightarrow$ L2 listening proficiency" had the largest effect size while the path "Intrinsic motivation $\rightarrow$ L2 listening strategy $\rightarrow$ L2 linguistic knowledge $\rightarrow$ L2 listening anxiety $\rightarrow$ L2 listening proficiency" was the weakest link in our model.

It is also clear, given the moderate effect size of the mediation path, that intrinsic motivation plays a role in more frequent use of L2 listening strategies, which increases L2 linguistic knowledge, ultimately improving L2 listening proficiency. Furthermore, L2 linguistic knowledge makes a modest contribution to L2 listening proficiency through reducing L2 listening anxiety.

Table 5 AVE values and squared correlations of each construct

\begin{tabular}{llll}
\hline Latent variables & AVE & $r$ & $r^{2}$ \\
\hline Intrinsic Motivation & .724 & -.256 & .065 \\
$\leftrightarrow$ L2 Listening Anxiety & .617 & & \\
Intrinsic Motivation & .724 & .600 & .360 \\
$\leftrightarrow$ L2 Listening Strategy & .845 & & \\
Intrinsic Motivation & .724 & .287 & .082 \\
$\leftrightarrow$ L2 Linguistic Knowledge & - & & .266 \\
L2 Listening Anxiety & .617 & -.516 & \\
$\leftrightarrow$ L2 Listening Strategy & .845 & -.577 & .332 \\
L2 Listening Anxiety & .617 & & .230 \\
$\leftrightarrow$ L2 Linguistic Knowledge & - & .480 & \\
L2 Listening Strategy & .845 & & \\
$\leftrightarrow$ L2 Linguistic Knowledge & - & & \\
\hline
\end{tabular}


Table 6 Path loadings of the final structural model

\begin{tabular}{|c|c|c|c|c|c|}
\hline & B & $\beta$ & S.E & $t(=$ C.R. $)$ & $p$ \\
\hline $\mathrm{Int} \rightarrow$ Strat & .383 & .593 & .047 & 8.199 & $* * *$ \\
\hline Strat $\rightarrow$ Kno & 14.034 & .484 & 1.959 & 7.165 & $* * *$ \\
\hline Strat $\rightarrow$ Anx & -.497 & -.278 & .144 & -3.451 & $* * *$ \\
\hline $\mathrm{Kno} \rightarrow \mathrm{Anx}$ & -.029 & -.468 & .005 & -5.849 & $* * *$ \\
\hline $\mathrm{Kno} \rightarrow \mathrm{LC}$ & .168 & .654 & .015 & 10.983 & $* * *$ \\
\hline Anx $\rightarrow L C$ & -1.018 & -.244 & .261 & -3.903 & $* * *$ \\
\hline
\end{tabular}

The purpose of the present study was to investigate the particular roles of the cognitive and affective factors that account for L2 listening proficiency in language learners at the lower end of the proficiency spectrum. With respect to the role that selfdetermined motivation plays in L2 listening proficiency, the above results indicate that among the subtypes of self-determined motivation, intrinsic motivation was the most significant predictor for L2 listening proficiency. This finding is consistent with evidence from previous studies suggesting that the more intrinsically motivated L2 learners are, the greater the increase in their L2 listening proficiency level (Pae 2009; Vandergrift 2005). Tangentially related to this, others have proposed that learners who are further along on the continuum of increasing self-determination will be more likely to use L2 learning strategies more frequently and in better combinations, and more willing to invest the time and effort required for self-regulatory learning (MacIntyre and Noels 1996; Noels 2009) - a finding confirmed in our results. This robust connection between intrinsic motivation and L2 listening strategy use may explain why the more intrinsically motivated students reported more autonomous, self-regulated learning than those who were not. The implication of this link between intrinsic motivation and self-regulated learning is that L2 listening strategy use can be facilitated through intrinsic motivation. Clearly, finding ways to increase learners' intrinsic motivation should be an instructional priority if greater L2 listening strategy use is the goal. One

Table 7 Total, direct, and indirect effects of path loadings

\begin{tabular}{|c|c|c|c|c|c|c|c|}
\hline \multirow[t]{2}{*}{$\mathrm{H}$} & \multirow[t]{2}{*}{ Relationship } & \multicolumn{2}{|c|}{ Direct Effect } & \multicolumn{2}{|c|}{ Indirect Effect } & \multicolumn{2}{|c|}{ Total Effect } \\
\hline & & $\bar{B}$ & $\beta$ & $\bar{B}$ & $\beta$ & $\bar{B}$ & $\beta$ \\
\hline $\mathrm{H} 1$ & Intrinsic $\rightarrow$ Strat & .383 & $.593 * * *$ & & & .383 & $.593 * *$ \\
\hline $\mathrm{H} 2$ & Intrinsic $\rightarrow$ Knowl & & & 5.371 & $.287^{* *}$ & 5.371 & $.287^{* *}$ \\
\hline $\mathrm{H} 3$ & Intrinsic $\rightarrow$ Anxiety & & & -.345 & $-.300^{* *}$ & -.345 & $-.300^{* *}$ \\
\hline $\mathrm{H} 4$ & Intrinsic $\rightarrow \mathrm{LC}$ & & & 1.256 & $.261^{* *}$ & 1.256 & $.261^{* *}$ \\
\hline H5 & Strat $\rightarrow$ Knowl & 14.034 & $.484^{* * *}$ & & & 14.034 & $.484^{* *}$ \\
\hline H6 & Strat $\rightarrow$ Anxiety & -.497 & $-.278^{* * *}$ & -.405 & $-.227^{* *}$ & -.902 & $-.505^{* *}$ \\
\hline $\mathrm{H} 7$ & Strat $\rightarrow L C$ & & & 3.282 & $.440^{* *}$ & 3.282 & $.440^{* *}$ \\
\hline $\mathrm{H} 8$ & Knowl $\rightarrow$ Anxiety & -.029 & $-.468^{* * *}$ & & & -.029 & $-.468^{* *}$ \\
\hline $\mathrm{H} 9$ & Knowl $\rightarrow \mathrm{LC}$ & .168 & $.654^{* * *}$ & .029 & $.114^{* *}$ & .198 & $.768^{* *}$ \\
\hline $\mathrm{H} 10$ & Anxiety $\rightarrow \mathrm{LC}$ & -1.018 & $-.244^{* * *}$ & & & -1.018 & $-.244^{* *}$ \\
\hline
\end{tabular}

\section{Note. $\mathrm{H}=$ Hypothesis}

${ }^{* * *} p \leq .001$

${ }^{* *} p \leq .01$ 
Table 8 Indirect effect sizes of all variables on L2 listening proficiency

\begin{tabular}{ll}
\hline Mediating path & Indirect effect size \\
\hline Intrinsic $\rightarrow$ Strategy $\rightarrow$ Knowledge $\rightarrow$ LC & .188 \\
Intrinsic $\rightarrow$ Strategy $\rightarrow$ Knowledge $\rightarrow$ Anxiety $\rightarrow$ LC & .033 \\
Intrinsic $\rightarrow$ Strategy $\rightarrow$ Anxiety $\rightarrow$ LC & .040 \\
Strategy $\rightarrow$ Knowledge $\rightarrow$ LC & .317 \\
Strategy $\rightarrow$ Knowledge $\rightarrow$ Anxiety $\rightarrow$ LC & .055 \\
Strategy $\rightarrow$ Anxiety $\rightarrow$ LC & .068 \\
Knowledge $\rightarrow$ Anxiety $\rightarrow$ LC & .114 \\
\hline
\end{tabular}

way of accomplishing this may be through creating a less-controlled learning atmosphere that allows learners more autonomy, and by providing learners with feedback that increases their intrinsic motivation (Noels et al. 1999; Noels 2001).

We were also interested in the nature of the effect that L2 listening strategy use has on L2 listening proficiency. Unexpectedly, the path loading from L2 listening strategy use to L2 listening proficiency was shown to be nonsignificant, and we found instead that L2 linguistic knowledge fully mediates their relationship. What this implies is that L2 listening strategy instruction may not improve learners' L2 listening proficiency in the absence of certain prerequisites, particularly when L2 linguistic knowledge has yet to reach an adequate level that might allow L2 listening strategies to be applied. Previous research does confirm this finding that learners at higher levels of ability generally exhibit more varied and more effective L2 strategy use (Griffiths and Oxford 2014). On the other hand, the fact that the strength of the path coefficient from L2 linguistic knowledge to L2 listening proficiency was the highest of all provides evidence for the relative importance of L2 linguistic knowledge for L2 listening proficiency, and this appears to implicate the somewhat controversial notion of a linguistic threshold. The central idea underpinning this explanation, also investigated by Vandergrift (2006) in the context of L2 listening, is that learners' L2 comprehension may suffer if their L2 linguistic knowledge is under a desired threshold. The fact that, in our structural model, L2 linguistic knowledge explained the most variance in L2 listening proficiency confirms that both grammar knowledge and vocabulary knowledge are key factors in determining L2 listening proficiency. Our findings clearly suggest that provision for L2 listening strategy instruction may first need to take learners' L2 linguistic knowledge into account. A lack of L2 linguistic knowledge may hinder the use of L2 listening strategies and increase L2 listening anxiety, thus negatively affecting L2 listening proficiency. However, the larger issue from our findings is not whether L2 listening is more a question of listening ability or language proficiency as Vandergrift (2006) proposes, but that language proficiency actually appears to determine listening ability.

As we expected, L2 listening anxiety had a negative relationship with L2 linguistic knowledge and the use of L2 listening strategies. This suggests that, the higher the learners' use of L2 listening strategies, the lower their L2 listening anxiety is likely to be. Additionally, as levels of L2 linguistic knowledge become greater, the less L2 listening anxiety learners are likely to have (see also Dewaele and MacIntyre 2014). These findings offer additional justification both for intentional L2 listening strategy instruction and for increasing L2 linguistic knowledge in order to decrease L2 listening anxiety and thereby improve L2 listening proficiency. Taken all together, the structural relationships among the pertinent factors affecting 
L2 listening proficiency begin from intrinsic motivation which directly affects L2 listening strategy use, indicating that intrinsic motivation only indirectly affects L2 listening proficiency mediated through all the other variables. L2 listening strategy use has an indirect impact on L2 listening proficiency mediated through L2 linguistic knowledge and L2 listening anxiety as well as an indirect impact on L2 listening proficiency. Furthermore, L2 linguistic knowledge directly affects L2 listening proficiency and also indirectly affects L2 listening proficiency mediated through L2 listening anxiety. Last, L2 listening anxiety only directly affects L2 listening proficiency.

\section{Conclusion}

The purpose of this study was to test a structural model-based on combined empirical evidence and theoretical considerations - of several crucial affective and cognitive factors for L2 listening proficiency. Our data indicate that among the subtypes of selfdetermined motivation, intrinsic motivation was the most significant predictor for L2 listening proficiency. While this finding is not entirely new or surprising, we further established a robust connection between intrinsic motivation and L2 listening strategy use, with the more intrinsically motivated students reporting increased self-regulated learning behavior. With regard to the relationship between L2 strategy use and L2 listening proficiency, we discovered no direct link. Instead, it was only through the mediation of L2 linguistic knowledge that the former impacted the latter. Furthermore, in our model L2 linguistic knowledge explained the most variance in L2 listening proficiency, which provides evidence that both grammar knowledge and vocabulary knowledge are key factors in determining L2 listening proficiency that may at certain levels even override other cognitive and affective factors-in this case, L2 listening strategy use. Listening anxiety had a negative relationship with the two cognitive variables L2 linguistic knowledge and L2 listening strategy use. This provides further confirmation that the higher individuals' levels of L2 linguistic knowledge and L2 listening strategyuse are, the lower their L2 listening anxiety is likely to be.

Several limitations remain in the present study. First, our measurement of anxiety posed several problems during the EFA and CFA: we could not identify meaningful subfactors of L2 listening anxiety and ultimately included only two items in our analysis (i.e., those with a factor loading value of greater than .7). Secondly, given the large number of tests and questionnaires we administered to our participants we used only a measure of vocabulary breadth (i.e., the VLT) to represent vocabulary knowledge, but future research studying the effect of vocabulary knowledge on L2 listening could build on this by measuring-by default-both the depth and breadth of vocabulary knowledge. Finally, in focusing primarily on the cognitive and affective constructs in our model, we did not concern ourselves with the impact of other individual variables on L2 listening proficiency (e.g., gender, L2 ability level, grade level). Potential future studies could employ multi-group analysis to investigate whether group differences exist in the structural relationships between factors influencing L2 listening for these characteristics. Despite these limitations, by investigating the combined causal relationships among cognitive and affective factors which hinder or facilitate successful L2 listening, this study is expected to contribute to current understanding and open potential avenues for continued advances in this domain. We believe that it is only through this type of integral view of learners' L2 listening success that the field can move forward. 


\section{Authors' contributions}

SB participated in the design of the study and completed the data collection and data analysis, and was involved in the writing of the manuscript. PH helped to draft the manuscript and participated in the interpretation of the results. Both authors read and approved the final manuscript.

\section{Authors' information}

This study is based on research undertaken by the first author for a graduate degree at the corresponding author's institution.

\section{Competing interests}

The authors declare that they have no competing interests.

Received: 11 May 2016 Accepted: 13 August 2016

Published online: 18 August 2016

\section{References}

Andringa, S., Olsthoorn, N., van Beuningen, C., Schoonen, R., \& Hulstijn, J. (2012). Determinants of success in native and non-native listening comprehension: an individual differences approach. Language Learning, 62(s2), 49-78.

Bekleyen, N. (2009). Helping teachers become better English students: causes, effects, and coping strategies for foreign language listening anxiety. System, 37, 664-675.

Boo, Z., Dörnyei, Z., \& Ryan, S. (2015). L2 motivation research 2005-2014: understanding a publication surge and a changing landscape. System, 55, 145-157.

Brunfaut, T., \& Révész, A. (2015). The role of task and listener characteristics in second language listening. TESOL Quarterly, 49, 141-168.

Buck, G. (2001). Assessing listening. Cambridge: Cambridge University Press.

Butler, Y. (2015). English language education among young learners in East Asia: a review of current research (2004-2014). Language Teaching, 48, 303-342.

Chang, A. C.-S. (2007). The impact of vocabulary preparation on L2 listening comprehension, confidence and strategy use. System, 35, 534-550.

Cohen, A. (2014). Strategies in learning and using a second language (2nd ed.). New York: Routledge.

Deci, E. L., \& Ryan, R. M. (1985). Intrinsic motivation and self-determination in human behavior. New York: Plenum.

Deci, E. L., \& Ryan, R. M. (2000). Self-determination theory and the facilitation of intrinsic motivation, social development, and well-being. American Psychologist, 55, 68-78.

Dewaele, J.-M., \& Macintyre, P. D. (2014). The two faces of Janus? Anxiety and enjoyment in the foreign language classroom. Studies in Second Lanquage Learning and Teaching, 4, 237-274.

Dörnyei, Z. (2001). New themes and approaches in L2 motivation research. Annual Review of Applied Linguistics, 21, 43-59.

Dörnyei, Z., \& Ryan, S. (2015). The psychology of the language learner revisited. New York: Routledge.

Dörnyei, Z., \& Ushioda, E. (2013). Teaching and researching motivation (2nd ed.). New York: Routledge.

Elkhafaifi, H. (2005). Listening comprehension and anxiety in the Arabic language classroom. The Modern Language Journal, 89, 206-220.

Goh, C. (2000). A cognitive perspective on language learners' listening comprehension problems. System, 28, 55-75.

Goh, C. (2008). Metacognitive instruction for second language listening development: theory, practice and research implications. RELC Journal, 39, 188-213.

Grabe, W., \& Stoller, F. (2013). Teaching and researching reading (2nd ed.). New York: Routledge.

Graham, S., \& Macaro, E. (2008). Strategy instruction in listening for lower-intermediate learners of French. Language Learning, 58, 747-783.

Graham, S., Santos, D., \& Vanderplank, R. (2010). Strategy clusters and sources of knowledge in French L2 listening comprehension. Innovation in Language Learning and Teaching, 4, 1-20.

Griffiths, C. (2013). The strategy factor in successful language learning. Bristol: Multilingual Matters.

Griffiths, C., \& Oxford, R. L. (2014). The twenty-first century landscape of language learning strategies: introduction to this special issue. System, 43, 1-10.

Horwitz, E. K. (2001). Language anxiety and achievement. Annual Review of Applied Linguistics, 21, 112-126.

Horwitz, E. K. (2010). Foreign and second language anxiety. Language Teaching, 43, 154-167.

Hsiao, T., \& Oxford, R. L. (2002). Comparing theories of language learning strategies: a confirmatory factor analysis. The Modern Language Journal, 86, 368-383.

Hu, G., \& McKay, S. (2012). English language education in East Asia: some recent developments. Journal of Multilingual and Multicultural Development, 33, 345-362.

Jung, Y. S. (2004). Listening strategies and listening anxiety in EFL environment. English Language Teaching, 16, 261-284.

Kim, J. (2002). Anxiety and foreign language listening. English Teaching, 57(2), 3-34.

Kim, J. (2005). The reliability and validity of a foreign language listening anxiety scale. Korean Journal of English Language and Linguistics, 5, 213-235.

Kim, S.-Y., \& Park, K.-R. (2006). An investigation into the association between learner anxiety and strategy use and English listening and reading. Foreign Languages Education, 13, 93-120.

Kim, Y.-e. (2008). The roles of breadth and depth of vocabulary knowledge in listening comprehension. English Language Teaching, 20, 143-165.

Kline, R. B. (2010). Principles and practice of structural equation modeling (3rd ed.). New York: Guilford Press.

Lee, S.-J., \& Lee, K.-R. (2007). Analysis of secondary students' English listening strategy and listening anxiety. Studies in Foreign Language Education, 21, 129-153.

Maclntyre, P. D., \& Gregersen, T. (2012). Affect: the role of language anxiety and other emotions in language learning. In S. Mercer, S. Ryan, \& M. Williams (Eds.), Psychology for language learning: Insights from research, theory \& practice (pp. 103-118). Basingstoke: Palgrave. 
Maclntyre, P. D., \& Noels, K. (1996). Using social psychological variables to predict the use of language learning strategies. Foreign Language Annals, 29, 373-386.

Mecartty, F. (2000). Lexical and grammatical knowledge in reading and listening comprehension by foreign language learners of Spanish. Applied Language Learning, 11, 323-348.

Mills, N., Pajares, F., \& Herron, C. (2006). A reevaluation of the role of anxiety: self-efficacy, anxiety and their relation to reading and listening proficiency. Foreign Lanquage Annals, 39, 273-292.

Ministry of Education, Science, and Technology (MEST). (2011). English curriculum (Proclamation of the Ministry of Education, Science and Technology \# 2011-361, Separate volume 14). Seoul, Korea.

Nation, I. S. P. (2006). How large a vocabulary is needed for reading and listening? The Canadian Modern Language Review, 65, 59-82.

Noels, K. (2001). Learning Spanish as a second language: learners' orientations and perceptions of their teachers' communication style. Language Learning, 51, 107-144.

Noels, K. (2009). The internalisation of language learning into the self and social identity. In Z. Dörnyei \& E. Ushioda (Eds.), Motivation, language identity and the L2 self (pp. 295-313). Bristol: Multilingual Matters.

Noels, K., Clément, R., \& Pelletier, L. (1999). Perceptions of teachers' communicative style and students' intrinsic and extrinsic motivation. The Modern Language Journal, 83, 23-34.

Noels, K., Pelletier, L., Clément, R., \& Vallerand, R. (2000). Why are you learning a second language? Motivational orientations and self-determination theory. Language Learning, 50, 33-64.

Noels, K., Pelletier, L., \& Clément, R. (2001). Intrinsic, extrinsic, and integrative orientations of French Canadian learners of English. The Canadian Modern Language Review, 57, 424-442.

O'Malley, J. M., \& Chamot, A. U. (1990). Learning strategies in second language acquisition. Cambridge: Cambridge University Press.

Oxford, R. L. (1990). Language learning strategies: what every teacher should know. Boston: Heinle \& Heinle.

Pae, T.-I. (2009). An explanatory model of EFL listening comprehension. English Teaching, 64, 399-418.

Pae, T.-I. (2013). Skill-based L2 anxieties revisited: their intra-relations and the inter-relations with general foreign language anxiety. Applied Linguistics, 32, 232-252.

Rost, M. (2007). 'I'm only trying to help': a role for interventions in teaching listening. Language, Learning and Technology, 11, 102-108.

Rost, M. (2013). Teaching and researching listening (2nd ed.). New York: Routledge.

Schmitt, N., Schmitt, D., \& Clapham, C. (2001). Developing and exploring the behaviour of two new versions of the Vocabulary Levels Test. Language Testing, 18, 55-88.

Shiotsu, T., \& Weir, C. (2007). The relative significance of syntactic knowledge and vocabulary breadth in the prediction of reading comprehension test performance. Language Testing, 24, 99-128.

Stæhr, L. S. (2009). Vocabulary knowledge and advanced listening comprehension in English as a foreign language. Studies in Second Language Acquisition, 31, 577-607.

Taylor, L., \& Geranpayeh, A. (2011). Assessing listening for academic purposes: defining and operationalising the test construct. Journal of English for Academic Purposes, 10, 89-101.

van Zeeland, H., \& Schmitt, N. (2013a). Incidental vocabulary acquisition through L2 listening: a dimensions approach. System, 41, 609-624.

van Zeeland, H., \& Schmitt, N. (2013b). Lexical coverage in L1 and L2 listening comprehension: the same or different from reading comprehension? Applied Linguistics, 34, 457-479.

Vandergrift, L. (1997). The strategies of second language (French) listeners: a descriptive study. Foreign Language Annals, 30, 387-409.

Vandergrift, L. (2003). Orchestrating strategy use: towards a model of the skilled second language listener. Language Learning, 53, 463-496.

Vandergrift, L. (2005). Relationships among motivation orientations, metacognitive awareness and proficiency in L2 listening. Applied Linguistics, 26, 70-89.

Vandergrift, L. (2006). Second language listening: listening ability or language proficiency? The Modern Language Journal, 90, 6-18.

Vandergrift, L. (2007). Recent developments in second and foreign language listening comprehension research. Language Teaching, 40, 191-210.

Vandergrift, L. (2008). Learning strategies for listening comprehension. In T. Lewis \& S. Hurd (Eds.), Language learning strategies in independent settings (pp. 84-102). Bristol: Multilingual Matters.

Vandergrift, L., \& Baker, S. (2015). Learner variables in second language listening comprehension: an exploratory path analysis. Language Learning, 65, 390-416.

Vandergrift, L., \& Goh, C. (2012). Teaching and learning second language listening: metacognition in action. New York: Taylor \& Francis.

Vandergrift, L., \& Tafaghodtari, M. (2010). Teaching L2 learners how to listen does make a difference: an empirical study. Language Learning, 60, 470-497.

Yeldham, M. (2016). Second language listening instruction: comparing a strategies-based approach with an interactive strategies/bottom-up skills approach. TESOL Quarterly, 50, 394-420.

Yeldham, M., \& Gruba, P. (2016). The development of individual learners in an L2 listening strategies course. Language Teaching Research, 20, 9-34. 